\title{
6 Juliusz Bardach and the agenda of socialist history of law in Poland
}

\author{
Marta Bucholc
}

\section{Introduction}

The history of law is situated somewhat ambiguously among other historical disciplines. On the one hand, the history of law is a 'history of something' (see Popper, 1994, pp. 470-471), confined to a particular object and to a disciplinespecific point of view from which history can be written. On the other hand, law is a special 'something' for at least two reasons.

One is the temporality of law, which makes it different from other subjects of historical inquiries. Current mathematical knowledge results from a long and winding path of historical development, but no awareness of this path is required to learn and apply state-of-the-art mathematics. Historical consciousness may sometimes be an enhancement, but it is always a luxury. However, historicity is inherent to law, at least in its form dominant in the modern West, because this form of law states the conditions of its own validity in temporal terms. Legal order is a succession of norms, which are either in force, no longer in force, replacing each other, or repealing and amending each other. Finding one's way round in this normative nexus requires some form of historical consciousness. This brings us to the second reason why law is a specific object of a 'history of something', namely, its direct connection to political power. History of law implies the situatedness of lawmakers. It has a side effect of relativizing and historicizing legal orders. While some legal orders, especially democratic ones, may be relatively immune to this operation, some others find it too much of a risk for their legitimacy to admit that there was a law before them, as that may imply that there will be a law after them.

That the latter point should apply to socialist regimes in Central and Eastern Europe after 1917 and 1945 is far from obvious. The Marxist philosophy that inspired the official ideology comprised an expressly historicist approach to social norms. Even though it insisted on the finality of history, it also posited a long succession of changing forms of production, each of them with its own particular normative setup. An examination of this historical process was the crux of historical materialism. The history of law should actually thrive under socialism. In most cases, however, it demonstrably did not, and one of the reasons was the fact that the philosophical and ideological tenet about history ending in communism 


\section{Marta Bucholc}

could not withstand the pressure of detailed analysis of the variety of the laws of the past and their political and cultural embeddedness. This objection against the history of law would in fact be common to all monocratic systems for which pluralism is a threat, even if it is only extending into the past. Incidentally, the argument should also work against comparative law: there would be little point in comparing socialist countries to one another, as they were all supposedly steering towards legal standardization, and the results of any comparison between a socialist and a capitalist legal order were taken for granted.

Furthermore, the role that the history of law played in the late 19th and early 20th centuries should be considered. At the time, in Europe, the history of law, especially if we include Roman law, was traditionally a necessary element of legal training and an important playfield for debates weighing on the legal reforms at the time, both in public and in private law. The political relevance of the history of law was indisputable, and so was the role of law as a carrier of national identities. In the early modern and modern period, law was ultimately tied to the national project and to the model of a nation-state, a connection reinforced by the high wave of modern constitutionalism (see Thornhill, 2011). The history of law was thus embedded in national history (for Germany, see Haferkamp, 2018). It became a natural point of resistance against any form of post-nationalist or internationalist modes of thinking. By the same token, the history of law could also form a foundation of the identity of the legal profession as a carrier of a disciplinary and professional ethos.

This brief overview of some among the many reasons why legal history could not thrive under socialism makes any proof to the contrary valuable. In this chapter, I undertake an analysis of the biographical and scientific trajectory of a Polish legal historian Juliusz Bardach (1914-2010). He was a scholar of exceptional standing in a socialist country, a remarkable feat in many ways. Poland was not only 'the merriest barrack in the Soviet camp', but it was also an exception from the point of view of academic history (for the socialist period, see Connelly, 2000). The old argument, according to which Poland can be treated as a mirror of all the problems of Central and Eastern Europe (Garrison Walters, 1988 , p. 170), does not work for the history of law. However, an exception makes it possible to triangulate an image of what might otherwise be mistaken for a universal course of a social process. The same reasoning applies to Bardach. He was not typical or representative-indeed, he was quite the opposite-but his biography 'allows us to follow almost a hundred years of uneasy history of Eastern Europe' (Sokalska, 2017, p. 18). His influence makes Bardach's case an excellent starting point for a study of the vicissitudes of legal history in Poland under socialism. The opinion of Henryk Olszewski that 'almost all historians of law in Poland can think of themselves as his students' (Olszewski, 2010, p. 163) is certainly shared by many: '[I]n retrospect, Bardach deserves to be called the most important figure in the historiography of law in Poland in the second half of the 20th century' (S. Salmonowicz quoted in Zakrzewski, 2016, p. 62).

Although Bardach's autobiographical notes remain unpublished (Szlachta, 2014, p. 80), it is only a matter of time before he becomes the subject of a full-fledged 
biography. As Tadeusz Rutkowski observed in his seminal book on political aspects of the organization of historical science in Poland in the first 25 years of the People's Republic, biographical studies of Polish historical sciences are still in a bad state' (Rutkowski, 2008, p. 19). However, a number of biographical sketches have been published, many of which I cite here. A detailed synopsis of Bardach's work on Lithuanian law by Tomasz Siewierski (2010) is particularly precious for a nonspecialist. As Rutkowski has pointed out (Rutkowski, 2008, p. 15), there are still too few critical monographic works on the history of historical science under socialism, and the same applies to historical-legal science. Nonetheless, a number of valuable contributions, first and foremost in Czasopismo Prawno-Historyczne, covered some aspects of the development of legal history under socialism and after 1989.

In this chapter, I do not attempt a prosopography of the history of law under socialism in Poland. Apart from a few concluding remarks, I do not read Bardach's life's work as a model for his (or any other) generation or cohort. Instead, I suggest reconstructing his contribution to what could be called 'the agenda of the history of law' in Poland after 1945: its general direction of research, including the selection of topics and the methodological strategies, as well as its relation to other disciplines and to its own disciplinary past before 1945 .

\section{Bardach's life at a historical intersection}

Juliusz Bardach was born into an assimilated Jewish family in Odessa in Russia in 1914, the oldest son of Mejer Bardach and Ottylia Neuding. ${ }^{1}$ His father was a dentist. In 1922, the family was repatriated to Poland, to Volodymyr-Volynskyi (then Włodzimierz Wołyński). At this point, Bardach-according to his handwritten curriculum vitae attached to his university enrolment file-started to learn Polish. At home, he was prepared for the second grade of gymnasium, and for six years he attended a public gymnasium in Włodzimierz. In his final grade, he changed to a private gymnasium, passed his maturity exam, and in 1933 enrolled as a law student at the Faculty of Law and Social Sciences of Stefan Batory University in Vilnius (then Wilno in Poland). On his registration form, Bardach entered his nationality and his mother tongue as Jewish.

\section{The beginnings of an academic career and the Second World War}

Poland before 1939 had five state universities and more than 20 state and nonstate academic higher schools (not to mention institutions of religious formation, one of them, Chachmei Lublin Yeshiva, among the most renowned in the world) (see Bajerski, 2016). In this academic scene, legal science enjoyed an important place. The curricula in law were dominated by the Austro-Hungarian model, since only in the Austrian partition had Polish been the language of university teaching before 1918, which gave the former Austro-Hungarian academics an advantage. In 1920, a ministerial ruling introduced a unified university curriculum in legal 


\section{Marta Bucholc}

sciences that lasted until the first decade after the war (Wolodkiewicz, 2015). The balance between scientific formation and the needs of practical professional training was achieved by the domination of theoretical and historical subjects in the first two years, including Roman law as a propaedeutic of civil law, legal theory, the history of Polish law and state regimes, and the history of law and state regimes in Western Europe. From the very beginning, this concept of legal education was heavily contested (see Marszał and Srokosz, 2010).

The high prestige of the history of law as well as its crucial role in academic teaching were an incentive for outstanding students. From the beginning of his studies, Bardach was a member of the seminar of Polish and Lithuanian law of Professor Stefan Ehrenkreutz (1880-1945). Ehrenkreutz would later become the last Rector of Batory University; he was a senator of the Polish Republic until 1938 and, in 1939, he supervised Bardach's master's thesis. Bardach also participated in seminars of Henryk Łowmiański (1898-1984) and of Wiktor Sukiennicki (1901-1983), who had once belonged to the Kelsen Circle in Vienna. During his studies, Bardach made a number of intellectual connections, which survived the war and proved vital for his later personal ties and his academic profile. He also became a political activist, a member of the socialist youth movement and, after 1935, a member of the Polish Socialist Party (for details on Bardach's student years, see Filaszkiewicz, 2016).

In 1939, Bardach had to leave Vilnius to escape the Soviets. In 1942, the Nazis killed his first wife, his parents, his sister and his uncle's family, who had all remained in Włodzimierz. The only surviving member of the family was Juliusz's brother, Janusz Bardach (1919-2002), who was sent to the Gulag. After the war, Janusz emigrated to the United States and made a name for himself as a surgeon as well as an author. ${ }^{2}$

Having survived in various parts of the Soviet Union until 1944, Juliusz decided to join the First Polish Army, organized by the Soviets. He would remain in the army for some time, reaching the rank of colonel in the political division. Soldiers with the rare benefit of higher education were often placed there and given the task of politically educating soldiers, many of whom had very little sympathy with Marxist-Leninist ideology. In 1946, Bardach was nominated military attaché at the Polish Embassy in Moscow, where he remained until 1948. He was approached by the authorities of the Faculty of Law of the newly established University of Łódź in 1945 as a potential docent. However, the army refused to let him go, even though Łódź in post-war times was a political project of pivotal importance, including a new people's university meant to take up the space left by the devastated bourgeois Warsaw academia (see Zysiak, 2018).

\section{Second beginnings}

While still in active service, Bardach obtained a doctorate at the prestigious Faculty of Law of the Jagiellonian University in Cracow, based on a dissertation on Adoption in Lithuanian Law of the 15th and 16th centuries, which he had published in 1938. His supervisor was Professor Adam Vetulani (1901-1976), 
an excellent specialist in church and canon law (a subject that disappeared from university teaching after the war) and the history of Polish law. Olga Filaszkiewicz explains that the reason to approach Vetulani was that the original supervisor, Ehrenkreutz, died in 1945 (Filaszkiewicz, 2016, p. 94). Vetulani was most definitely not a politically correct figure after 1945. Nevertheless, upon his return from abroad in 1947 he became the Chair for the History of Polish State and Law and later a dean of the Faculty of Law, although he was never a party member and for many years was under surveillance by the Secret Service. Bogdan Szlachta quotes Bardach remembering his concern that because of his declared Marxist views and his pre-war socialist card, he could have been an undesirable supervisee for Vetulani, an unwanted addition to 'his school' (Szlachta, 2014, p. 80). Bardach remained close to Vetulani throughout his academic career, and he was one of the eight doctoral students supervised by him who would all become law professors. In this way, the influence of Bardach is also a part of a larger historical trend. Vetulani was a direct continuator of the 19th century 'Cracow school of historians' (see Mączak, 1993, p. 236; Wandycz, 1992). Bardach's influence would thus be instrumental in extending this school's impact into the 20th and then the 21 st century. Vetulani was also known in the West: among other things, he received honorary doctorates from Strasbourg and Nancy, which he could not receive in person because the authorities would not let him travel abroad. Through liaison with Vetulani, Bardach, still a highranking officer of the People's Army, would thus become a friend with a person of high-bourgeois origin, close to the Church, including the future pope John Paul II, Karol Wojtyła, who also studied at Jagiellonian University and was later Bishop of Cracow (see Dobra starość..., 2007). Bardach even protected Vetulani from a politically and ideologically motivated relocation to Wrocław (cited in Szlachta, 2014, pp. 81-82).

In 1950, Bardach was released from the army with very unfavourable notifications in his personal file: 'heard to express views hostile to the Soviet Union', and 'a pre-war socialist'. An official remark of this kind was a career killer in the army. However, as a Marxist researcher, Bardach was good enough for a university job (Zakrzewski, 2016, p. 58) and the Faculty of Law of the University of Warsaw employed him.

In my brief history of Polish sociology (Bucholc, 2016), I argued that there were two distinct roles that academics with a pre-war education played immediately after the war: survivors and supervisors. The war brought about catastrophic destruction of Polish universities, and two of them, Lwów and Wilno, were lost (while Germany lost the university in Breslau to Poland). However, those professors and docents who lived through the war, the Holocaust, the Nazi and Soviet occupations and the Warsaw Uprising of 1944, or who returned from emigration after 1945 were still a significant component of the human resources on which the new academia could be based. They brought with them their prewar research agendas, knowledge and international networking capital but also intellectual habits and academic ethos. They were survivors themselves, but through them and with them the traditions of pre-war university also survived, 
though sometimes in disguise. Many of the survivors never joined the party, and indeed the phenomenon of highest-ranking academics who were not party members was one of the particularities of Poland among the Eastern bloc countries. However, the survivors were few and moreover, from the point of view of the Communist Party, they were too unreliable, even though some of them, like the prominent sociologist Józef Chałasiński, seemed genuinely to link their fate to that of the new regime early on (see Bucholc, 2016, pp. 20-21). Hence the political necessity of politically reliable supervisors.

Most of the supervisors were recruited from the cohort born in 1920. They ensured ideological cohesion, attacked pre-war academics and were quickly included in the academic teaching, transmitting the new ideology to their students. Many of them would later emigrate and become well-known European scholars, like some of the members of the so-called Warsaw school of the history of ideas, including Leszek Kołakowski or Bronisław Baczko (see Bucholc, 2017a). However, they were naturally themselves educated either before the war or by survivors after the war, thus - through a kind of intellectual osmosis-becoming carriers of pre-war, bourgeois academic culture and scientific knowledge. The 'survivor effect' translated into very practical things that were far from obvious in the academy in the late 1940s and early 1950s: the command of foreign languages, the experience of travelling abroad for research, the direct or indirect link with colleagues in the West and the personal experience of pluralism and free debate in science.

Bardach's role was initially one of a supervisor, and 'was often perceived as a political imposition on science' (Salmonowicz cited in Zakrzewski, 2016, p. 58). Rutkowski summarized the period of Stalinism at the University of Warsaw thus: ${ }^{3}$

The years 1949-1955 were a time of strong ideological pressure at the University of Warsaw [...]. It was followed by personal changes in the academic staff, first and foremost at the faculties which were important for ideological reasons: Philosophy, History, Law, Political Economy and the Faculty of Journalism, which was founded at the end of this period. Academics came to them by way of a speedy 'party' promotion (including Juliusz Bardach, Rafał Gerber, Stanisław Ehrlich, Julian Hochfeld). (Rutkowski, 2016, p. 442)

In the 1950s, Bardach spoke at a number of congresses and symposia, following the party line, sometimes using a very sharp tone (Rutkowski, 2008, p. 153). He also performed a 'party lustration' at the Instytut Zachodni in 1952 (Rutkowski, 2008 , p. 226). In the late 1940s, some form of methodological pluralism was still in place by sheer force of facts. As Rutkowski points out, commenting on the first post-war (and seventh ever) General Congress of Polish Historians in 1948 in Wrocław, which was dedicated to the so-called 'Recovered Territories' (Ziemie Odzyskane)—'there was next to no Marxist historical scholarship on the Recovered Territories' at the time (Rutkowski, 2008, p. 124). Polish historical 
science had to learn Marxism as it went along, and the political reinforcement of history departments was a necessity. Hence, the interplay of ideology and science, a development that was much more complicated than any retrospective projection could possibly imagine. To name just one example: Bardach emphatically opposed the presence of 'political Catholics' in the Instytut Zachodni (Rutkowski, 2008, p. 226), but Stanisław Alexandrowicz remembers that it was his intervention in 1952-1953 that saved the university job of Brygida Kürbis, who was fired because she regularly attended Catholic masses (Alexandrowicz, 2010 , p. 155). Bardach's argument was the high quality of Kürbis' scientific work, and she did indeed become a history professor herself.

In 1950, Bardach was, according to Rutkowski, 'the rising star of party historical science' (Rutkowski, 2008, p. 153). He was, of course, a party member, and even though he underlined his pre-war socialist commitment on many occasions, he did not resign his Communist Party membership until 1990, which many others did, especially in 1968 and 1981. In 1950, Bardach became an Acting Professor and an Acting Dean of the Faculty of Law as a result of the Marxist reorganization of the academia in historical science. In the same year, any ties with the Western community of historians were cut and a period of intensive party work on the new design of Polish historical science followed (Rutkowski, 2008 , p. 160). In this process of ideological restructuring, the history of law and state was perceived as part of the agenda of the Marxist science of history more than the Marxist science of law. It was no longer the history of state regime, and in 1950 Bardach himself requested the terminological shift from 'state regime' (ustrój) to 'state' (pan'stwo) as better expressing the new Marxist orientation (Z prac...., 1950, p. 99). However, already in 1951, he insisted on the relative autonomy of the history of law, arguing as follows:

Just as we cannot separate the legal and state developments from their socioeconomic basis as it was usually done by bourgeois scholars, we cannot reduce the interest in state and legal developments to the study of their base or, which also did happen, to the study of the development of the forces of production. To replace law with economics, and the history of the state and the law with social or economic history would be a vulgarisation of Marxism. (Bardach, 1951, pp. 2-3)

\section{The Thaw and 1968}

The universal cesura of post-war academic and political history alike is, as in the Eastern bloc as a whole, the year 1956, which in Poland goes by the name of the 'October Thaw of 1956'. The second half of the 1950s was a period of revival in Polish intellectual life, of renewing or establishing new contacts in the West and of a certain relaxation in ideological rigor. In 1955, Bardach became a university professor, and in 1960 an 'ordinary professor', employed in the Institute of History of Law established in 1952. He also held a post at the Polish Academy of 


\section{Marta Bucholc}

Sciences, where he directed the historical part of the Institute of Legal Sciences. As a direct consequence of the Thaw, the contacts between Polish and French historians were renewed, and in June 1957, Bardach, as one of three Polish delegates, participated in a conference entitled 'The Days of History of Law' in Paris (Rutkowski, 2008, p. 314). In the 1950s, Bardach joined a number of committees responsible for preparing a new framework of historical studies in Poland.

The Thaw did not last long, an ideological offensive was soon relaunched and Bardach's star, one of the brightest immediately after 1956, started to fade. Halfway through the 1960s the opinion that he was 'too liberal' for the taste of the party was established (Rutkowski, 2008, p. 350). By 1967, Bardach lost his influence on the political line in science (Rutkowski, 2008, p. 435). In July 1963, still a member of the History Section of the Department of Education of the Central Committee, he became an object of interest to the Security Service and remained so until 1974 (Rutkowski, 2008, p. 435). In 1962, he had to move with all his team from the University of Warsaw to the Institute of History of Polish Academy of Sciences, directed by the leading medieval historian, Tadeusz Manteuffel. There he stayed on until his team was dissolved in 1968.

The year 1968 is a turning point whose ripple effect in Polish intellectual history is far from adequately reconstructed. As a result of the anti-Semitic campaign sponsored by the Soviet authorities, a purge was orchestrated by the party with little or no social resistance. Student protests at the University of Warsaw in March 1968, apparently analogous to those in the West, led to the expulsion of student leaders. A few professors who supported them were also fired, including Bronisław Baczko, Zygmunt Bauman, Włodzimierz Brus, Maria Hirszowicz, Leszek Kołakowski, and Stefan Morawski. Most of them would soon emigrate.

Bardach was one of the supporters of the students' protests. He was among the signatories of a letter to the Minister of Education defending students victimized by the security forces after a rally in Warsaw (Rutkowski, 2008, p. 470). His precarious situation at the time is reflected in the following words of the rector of the University of Warsaw at a meeting in which the crisis at the university was discussed:

It has been stressed that there is a strong pressure exercised on the part of professors on younger academic staff, for example in the Faculty of History by Prof. Gerber, Herbst, Manteuffel, in the Faculty of Law by Prof. Ehrlich, Katz-Suchy, Maneli, Bardach, and in the Faculty of Philosophy by Prof. Szacki, Baczko, Hirszowicz, Morawski. (Cited by Rutkowski, 2008, p. 522)

In this collection of names Bardach is accompanied by Baczko, Hirszowicz and Morawski, who would lose their jobs, but also, among the others, by Jerzy Szacki, a historian of ideas and the main representative of the Warsaw School of the history of ideas, and by Stanisław Ehrlich, who would soon supervise the doctorate of Jarosław Kaczyński, the future leader of the national-conservative party Prawo i Sprawiedliwość.

The year 1968 was a hard blow for the intelligentsia and for the academy. By the end of the 1960s, as many as 20,000 persons (the counts vary substantially), 


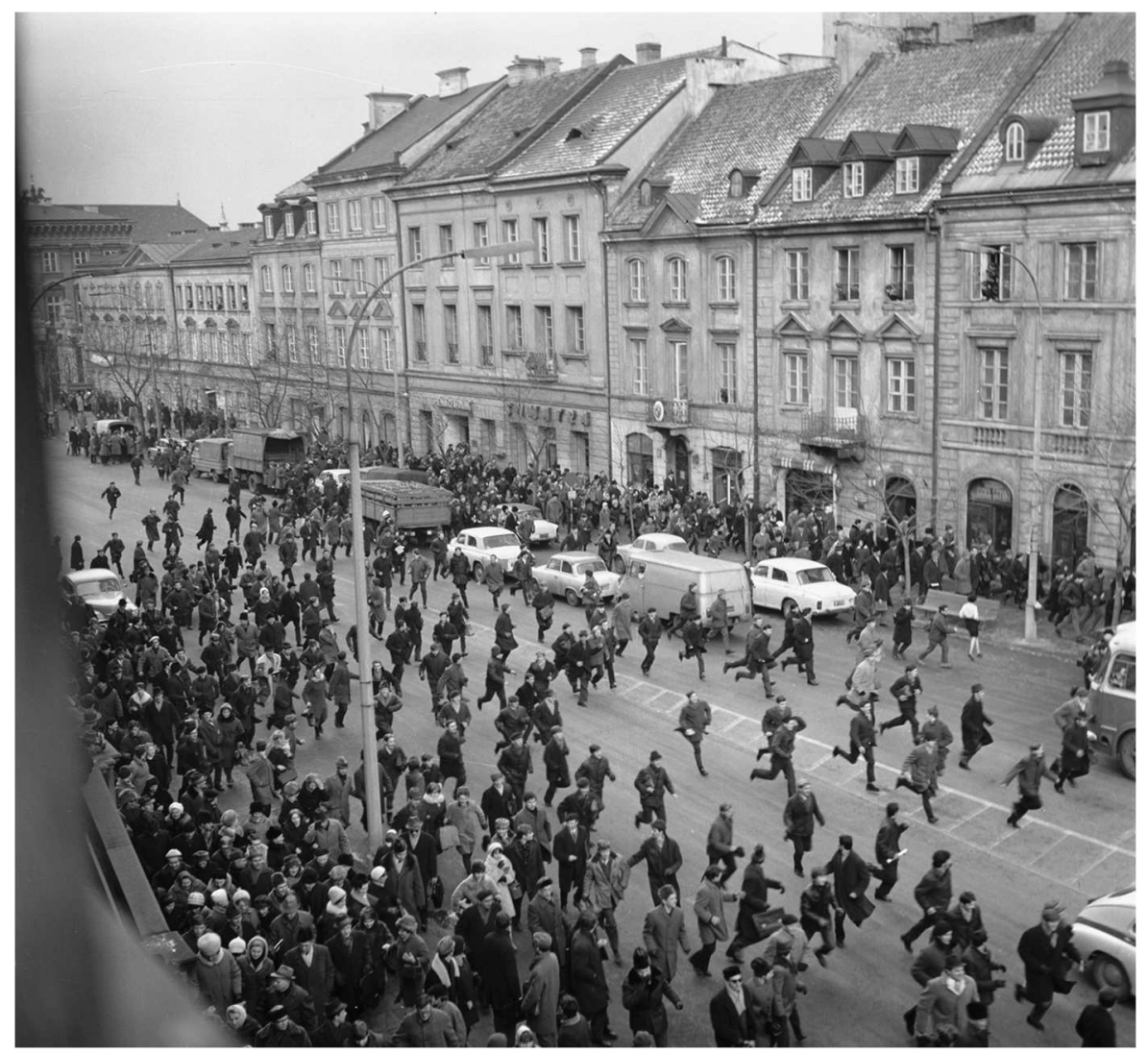

Figure 6.1 In 08.03.1968 thousands of students gathered in the courtyard of the University of Warsaw in protest against the violations of the extraterritoriality of the university. The militia attacked the youth and dispersed the demonstration.

persecuted or discriminated against due to their real or alleged Jewish origins or Zionist sympathies, left Poland with one-way travel documents stating that their holders were not Polish citizens. Those who did not emigrate were harassed and intimidated, and a deep re-organization of academic life followed. Bardach's team at the Polish Academy of Sciences was dispersed and the director himself was fired from the Academy. In his farewell speech, he stated his outrage at the scale of personnel changes in scientific institutions and journals, and he declared that the circumstances of 1968 reminded him of the 'worst methods of Stalinism' (Rutkowski, 2008, p. 499). The Security Service recorded the speech. However, Bardach remained a professor at the University of Warsaw, and he was neither removed from the party nor isolated from the international historical community, even though in 1970 during the XIII International Congress of Historical Sciences 


\section{Marta Bucholc}

in Leningrad, Polish authorities recommended him especially to the attention of the Komitet Gosudarstvennoy Bezopasnosti, the Soviet Committee for State Security (KGB) (Rutkowski, 2008, p. 532).

\section{Public appreciation after 1989}

Bardach lived through the Russian Revolution, two World Wars, the communist takeover in Poland and the many ups and downs of the Polish socialist state ending in the transformation of 1989. His life passed at a historical intersection between the East and the West, between the old imperial Europe of the 19th century, the totalitarianisms of the 20th and the new turn towards the West after the fall of the Eastern bloc. After 1989, Bardach as a senior scholar enjoyed public acknowledgment of his work and person. He obtained three honorary doctorates, two from Polish universities, Łódź (1995) and Warsaw (1996), ${ }^{5}$ followed by the University of Vilnius (1997). Jagiellonian University celebrated a renewal of his doctorate in 1999. Bardach, who had been decorated many times in his army days, received a number of civilian honours and awards after 1989, including the Grand Cross of the Order of Polonia Restituta (2002) and the Order for Merits to Lithuania (2006). He was also honoured by many festschrifts (the last one on his 90th birthday).

Bardach lived in Warsaw until his death in 2010. In 2013, an award named after him was funded by the Institute of the Grand Duchy of Lithuania in Kaunas (Szlachta, 2014, p. 84). In many eulogies, he was remembered by his colleagues, as well as by his students and supervisees, many of whom belonged to the elite of Polish historians.

\section{Bardach's oeuvre and how to understand it}

Bardach insisted that narrow specialization is not advisable in science. It would be neither possible nor necessary to characterize his large oeuvre in full (for a discussion in Polish, see Olszewski, 2010; Siewierski, 2012; Zakrzewski, 2016), but an overview of the most relevant features is crucial for an understanding of Bardach's role in the formation of the agenda of legal history in Poland.

\section{The Lithuanian connection}

The most remarkable aspect of Bardach's work is his lifelong study of Lithuanian law, in which he became the best-known specialist in Europe next to Łowmiański (Olszewski, 2010, p. 162). When still a student, he gave a talk on Lithuanian law at the General Congress of Polish Historians in Vilnius in 1935, and in 1938 he published a dissertation on adoption in the Lithuanian law. His warm feelings for Lithuania were born in his student days in Vilnius and never ceased throughout his lifetime. These sentiments were as useful as they were genuine: they were in line with Ehrenkreutz's seminar and it was an established area of research at the Stefan Batory University. The importance of Lithuanian law and in particular of 
the Lithuanian statutes for legal developments in Eastern Europe was an additional argument: in the early 1930s, it was neither an exotic interest nor a marginal one. Moreover, studies on the legal traditions of Poland-Lithuania were of great political relevance in the 1930s, and to pick Lithuania as a subject of research might have been at the time a good career move.

This was less the case after 1945. Poland-Lithuania, a sworn enemy of the Grand Duchy of Moscow was, after all, a feudal state that ruthlessly suppressed its peasantry, so its laws would hardly deserve much attention unless as an illustration of the tenets of Marxist philosophy. However, Bardach's initial prewar research was, in fact, far from it. In his work on adoption, he set out to document the existence of adoption as an institution of customary law, pointing out that even though it was not regulated in the statutes it was a part of everyday legal practice. It was not only a study in customary law (see Siewierski, 2012, p. 109): Bardach's analysis went in the direction of the historical study of 'living law' (lebendes Recht) à la Eugen Ehrlich and it proved a far-reaching independence of socially generated normative order from the statutory 'law in books'.

In all Bardach's work on Lithuania, he stressed the independence and originality of Lithuanian law and the fact that it was never 'colonized' (my term) by Polish tradition. This was, again, a double-edged argument: on the one hand, it went against pre-war and pre-partition Polish nationalism; on the other hand, it documented the longstanding independent legal tradition of Lithuania (then a Soviet republic). Conscious of this ambiguity, Bardach opposed nationalistic interpretations of Lithuanian legal history. Siewierski (2012) remarks that a paper that deserves attention in this context is Bardach's review of a book by a Lithuanian historian Jonas Žmuidzinas published in Paris in 1978 under the title Commonwealth polonolithuanien ou l'Union de Lublin (1569). In the review, Bardach insisted on the multifaceted, historically informed use of the notion of nationhood (see also Bardach, 2009). Bardach's interest in Lithuania was not popular with the communist authorities: in 1969, during the 10th General Congress of Polish Historians in Lublin, Bardach's presentation on the Polish-Lithuanian Union of Lublin was downgraded from a plenary lecture to an ordinary session (Zakrzewski, 2016, p. 60).

Bardach never prepared a comprehensive history of Lithuanian law, but among his 637 publications the Lithuanistic part (more than 120 according to Andrzej Zakrzewski, 2016, p. 59) is the largest coherent corpus, pertaining not only to the law but also to culture and the political history of the land, not only as a part of the union with Poland. ${ }^{6}$ Some of these works were written before the war and the vast majority after 1956. Many of them were translated into foreign languages, mostly French and Russian, but also Lithuanian, Belarusian, Italian, Ukrainian, English and Flemish.

\section{History of the Polish state and law}

Bardach's magnum opus reflected an encyclopaedic inclination shared by some of his contemporaries (see Sułek, 2012). It was a five-volume synthesis of the history of the Polish state and law, the first volume of which was dedicated to the 


\section{Marta Bucholc}

period before the 15th century and which Bardach authored himself while at the same time acting as an editor for the whole work. Five volumes published in Warsaw between 1957 and $1982^{7}$ cover the history of Polish state regimes and law, including public law, private law and procedure, until 1939. It is still a standard reference work, with an outreach far exceeding the field of legal history.

That the ambition to carry out such a far-reaching project became realizable at this very point bespeaks a need to synthesize the science of legal history based on new Marxist premises. On the other hand, it also indicates that there was a continuity between the pre-war efforts and the developments in the socialist historiography of law. In particular, Bardach contributed significantly to the study of Polish parliamentarism in the early modern and modern period, whose development he depicted with great attention to the internal logic of a form of polity, which developed parallel to the Western representative monarchies but under very different political and cultural conditions. The grand synthesis partly resulted from Bardach's teaching duties, and one additional product of this effort was a handbook Historia państwa $i$ prawa polskiego, co-authored by Bardach, Bogusław Leśnodorski and Michał Pietrzak, which was first published in 1976. The book was reprinted, revised and republished several times until 2009. As a result, for more than 30 years Bardach's work remained a standard handbook for law students in courses on Polish history, whose share in legal education gradually sunk after 1989, in line with the turn to 'dogmatic' aspects of law.

\section{Disciplinary ethos, methodology and the problem of periodisation}

In socialist Poland, the history of law was not separated from history in general, and legal historians played crucial roles in institutional historical science (Rutkowski, 2008, p. 14). Their impact seems, indeed, to have been stronger in history than in legal science. This is probably because in Poland-as opposed to certain other academic traditions-legal historians would usually specialize in the history of law only, doing little scholarly work in dogmatically oriented branches of law and not engaging in teaching beyond the historical subjects.

Bardach perceived historical-legal sciences as an interdisciplinary field, 'whose particular vocation it is to use its research techniques and its own approach to enrich both legal and historical science' (Bardach, 2001, p. 33). Even though this quote comes from a late paper, it does summarize Bardach's disciplinary attitude throughout his life rather well: he felt comfortable between epochs, languages and discourses (see Zakrzewski, 2016, pp. 60ff).

One particular feature of Bardach's general philosophy of legal historical research was his appreciation of the role of culture (Olszewski, 2015, p. 16). This was particularly evident in his attention to legal language and its link to vernacular languages. He was a student of 'travelling concepts' avant la lettre, and he endorsed the main tenet of this approach in today's cultural studies (see Bal, 2002), according to which the use of concepts and their transformations are part of cultural practices and cannot be separated from them. Particularly his work on the reception of law and on the comparative method belong to this field, in which he 
consciously traced the pathways of legal institutions, concepts and terminologies. The attention to customs, uses and habits—including linguistic habits—continued from pre-war times, and in his later work Bardach insisted that the history of law forms the core of socio-legal studies, which cannot put culture aside (Olszewski, 2015 , p. 17). This, in turn, made his stance problematic from the point of view of orthodox Marxist historiography: already in the 1950s, Bardach opposed the view that law was 'detached from general culture' and stressed continuities between the law and culture of Poland in various historical epochs (Olszewski, 2015, p. 17). In this manner, he did incorporate the dangers of the history of law to Marxism as a political ideology. Despite his self-declared commitment to Marxist methodology, his research was concerned with the historical and cultural contingencies of law and not with its determination by the forces of production and class struggles.

Against this culturalist interpretation of Bardach's work, an argument could be raised that he remained very much focused on the problem of periodization, particularly in the history of the Polish state and Polish representative government. The focus on periods of development as relatively closed units of historical progress was typical for Marxist historiography seeking finality and determination in the succession of phases. Rutkowski cites a significant clash between Polish and Soviet legal historians at a conference held in Poland in 1952, where Bardach himself reported a vivid discussion with Soviet guests, who very sharply criticized the 'negativist' vision of periodization presented by one of the speakers pleading for different periodizations for different socioeconomic formations. The Soviet guest, Arkady Sidorov, opted for a 'monist', linear and universalist model of periodization as the only one compatible with historical materialism (Rutkowski, 2008, p.196). Bardach adhered to the party line in this respect, but already in 1949, quoting Lenin, he argued that 'each division, each periodization is an attempt to impose a certain scheme, to divide the existing unity of history for our cognitive purposes' (Bardach, 1949, p. 23) and that it was in full accordance with historical materialism. Bardach's influence on the periodization of history of the Polish state, combined with his role as editor-in-chief of an encyclopaedic synthesis, was decisive and has only relatively recently been challenged (Zakrzewski, 2016, p. 59). Olszewski thus characterized Bardach methodological stance:

Juliusz Bardach created his workshop over decades. He construed it on the go, in the course of researching specific subjects. He did not think of himself as a methodologist of scientific research. His methodological texts were not conceived of as ambitious preaching on how historians of law should do their research, but they emerged as a result of years-long, persistent, indepth studies of sources. (Olszewski, 2015, p. 24)

There is an analogy here between Bardach and the historians of ideas from the Warsaw school. They remembered the role of methodology in their discussions, and to an extent also in their work, as marginal and ancillary (see Bucholc, 2017a): their method was dictated by the subject and was, in the sense of Paul K. Feyerabend, 'opportunistic'. From this point of view, Bardach's statement of 
1955, according to which 'the history of the state and law has no method of its own' (Historia... 1955, p. 3), is probably more than just lip service to the Marxism of the age.

\section{Numerous miscellanea, including the problem of Roman law}

Bardach's work included a large variety of miscellanea. One important section of this work were his biographical essays, most of which were dedicated to important figures in Polish 19th century historiography (Olszewski, 2015, p. 23). $\mathrm{He}$ also honoured many of his friends and colleagues with eulogies and memories. Olszewski interprets this as resulting from his conviction that science needs great personalities. However, it could also be seen as a commitment to the disciplinary tradition of history, which was also a national scientific and intellectual tradition, predating both the independent modern Polish state and socialism. Bardach's biographical essays may be indicative of a sense of belonging to a historically continuous community of scholars, and it may also be seen as a self-legitimizing effort: remembering is an instrument of inclusion. This focus on national tradition was common to many scholars of the time, including in particular Szacki (see Bucholc, 2017b). The feeling that tradition was not summarized in a satisfactory manner, that it was, in a way, left free-floating by the ideological turn after 1945, seems to have been pervasive in socialist Poland. It is somehow telling of the general climate in academia that this feeling evolved into reconstructive and commemorative projects initiated by scholars once affiliated with the Marxist party vanguard in their respective disciplines.

One other section of Bardach's miscellanea was Roman law. He dedicated little attention to this branch of historical legal studies, but in 1999, he published Statuty litewskie a prawo rzymskie. ${ }^{8}$ This book was a critical commentary to the new edition of the Lithuanian statutes, and it is, as far as can be confirmed based on the available bibliographies, the only major reference to Roman law in Bardach's oeuvre. It was a continuation of work started before 1939: Bardach remembered that Ehrenkreutz held a talk on the influence of Roman law on the Lithuanian statutes at a conference in 1935 in Vilnius, and he appointed Bardach as a discussant of his paper (Bardach, 2016, p. 521).

The position of Roman law in Polish socialist universities was marked by an interesting ambivalence. Some authors insist that the communist takeover with its subsequent law-making did in fact destroy the pre-war legal tradition in Poland as it did in other socialist countries of Central and Eastern Europe (see Kühn, 2011). However, the continued presence of Roman law as an important element in this tradition would be an argument to the contrary. Church law and canon law vanished from universities immediately after the war, sharing the fate of theology. Witold Wołodkiewicz cites a discussion during the First All-Polish Conference of Legal Historians in 1950, when Rafał Taubenschlag overtly stated that he 'did not see any chance for Roman law to develop in Poland' apart from legal papyrology and the studies of influence of Roman law on Polish law (Wołodkiewicz, 2012, p. 209). 
But Roman law - though criticized heavily by the new authorities-held on. Moreover, in the 1950s, Latin was still perceived as a must for law students, even those taking advantage of a speedy educational track created after the war to make up for the decimation of legal professions in the years 1939-1945 (Olszewski, 2017, p. 39). During the many reforms of university curricula, Roman law was reduced alongside other historical subjects and was perceived as a course of less and less propaedeutic value. Nevertheless, in the years 1944-1975, Roman law was taught throughout the land (see Czech-Jezierska, 2015). In the reform of 1975, however, based on the project of Bardach's student Jan Baszkiewicz, Roman law was combined with other historical subjects and separate lectures on Roman law were abandoned, which antagonised many legal historians (Wołodkiewicz, 2012, p. 210). In the 1980s, Roman law was reinstated as a subject in its own right, only to become subject to quite new adverse pressures after 1989. Throughout the socialist period, there was both human and intellectual capital in the field of Roman law in Poland, but Bardach's connection to this field was weak. For example, among the many personages he wrote about as a biographer or a friend there was not one Romanist. A passionate reviewer, he wrote only one review of a book on Roman law (more precisely, about its influence in Poland) (Bardach, 1991).

While the division of labour in the history of law after 1945 continued the prewar categorizations, the stress on Roman law and ancient law in the research agenda gradually weakened. A quantitative study of the contributions to the most important historical-legal journal published in Polish, Czasopismo PrawnoHistoryczne, since the 1990s, shows that Romanist papers were a thematic minority, with more than six times fewer contributions than Polish legal history, but also twice fewer than universal legal history and the history of legal and political doctrines and also almost twice fewer than various miscellanea (Materniak-Pawłowska and Krzymkowski, 2018, pp. 349-350). Roman law seems to have fallen victim to ideological considerations much more than any other branch of history of law.

\section{Vicissitudes and serendipities}

In the very tentative and incomplete balance of Bardach's biography and oeuvre, there are a few elements that have been given relatively little attention in the existing scholarship. The first of them is Bardach's Jewish origins. As Olena Sokalska remarked (Sokalska, 2017, p. 14): 'It is ironic to note that in Poland, it is often only after the death of an eminent Pole that two things about him are noticed: that he was eminent and that he was Jewish.' While in some biographical notes he is described as coming from a Jewish or Polish Jewish family, in many others it is not mentioned at all. Bardach was included in a publication edited by Wiesław KozubCiembroniewicz on scholars of Jewish origins at the Jagiellonian University with a very informative biographical essay by Bogdan Szlachta (2014). However, in this essay, apart from the first sentence of the biography, there is no mention of Jewishness as a factor in Bardach's life or career, even though the very nature of the 


\section{0}

publication seems to suggest that gathering a number of scholars under the same heading was dictated by the perceived salience of the criterion. Bardach's Jewish origins almost certainly played a role in his life after 1945 at least once, in 1968, but even in the narratives of this year, it is not mentioned at all. As far as publications are concerned, Bardach wrote one article in which the legal situation of Jews was discussed (Bardach, 1990, translated into French and English), and in 1989 he reviewed one book on the history of Jews in Poland in the 17th-18th centuries. Too little information is available precisely to assess the impact of Bardach's Jewish origins on his work or career, but the same factor played a key role in the biographies of many of his contemporaries in various scientific disciplines. Any prosopography of Polish legal historians should take this into account to ensure correspondence and synergy with studies in intellectual and academic history in Poland and in Central and Eastern Europe in general.

Another factor, which is definitely understated, is that Bardach was a native speaker of Russian. This aspect is not discussed in any of his biographies or eulogies cited here apart from one, by Stanisław Alexandrowicz:

I was particularly impressed by Juliusz Bardach during the joint meetings of Polish and Soviet historians. (...) During the sessions, the interventions by Prof. Bardach as a speaker, and even more as a discussant, were always very much to the point, and they were also bold. (...) Professor was able to conduct a polemic with the Soviet colleagues, very intelligently, but also in a very civil and diplomatic manner. In this, he spoke excellent literary Russian, more pre-revolutionary than Soviet. In view of his unusual tactfulness, his criticisms were never directly repudiated. (Alexandrowicz, 2010, p. 155)

An excellent command of Russian was not, by and large, a unique feature in academia, but it was not a universal feature either, and it was certainly a significant cultural asset. Among the historians educated in Poland before 1939, the orientation to the West was self-explanatory, which entailed a command of Western languages, in particular French and German. ${ }^{10}$ Russian was not a language of Polish historical science, apart from specialists in thematic fields where it was relevant. It does not take much to realize that a person capable of using an 'excellent' Russian would find it much easier to display tact and diplomatic skills in difficult talks with Soviet partners.

The part of Bardach's work published in Russian has been underplayed in recent accounts, and the focus is mostly on his many ties to Western academia and on his recognition in the West to which his numerous memberships and affiliations attest. ${ }^{11}$ However, he was also a regular member of various committees of socialist historians, in which Soviet academics played varying but important roles. Even though Polish historiography has liberated itself from full dependence from the Soviets since 1955 (Rutkowski, 2008, p. 265), it did not mean a break of bilateral and multilateral contacts and coordination within the Eastern bloc. 
Bardach's bibliography shows 11 books, articles and chapters published in Russian (including translations from Polish), at least 5 of them published after 1989, and 11 reviews of books published in Russian, some of them after 1989 and representing a wide range of topics. A few papers on the state of historical science in the USSR, on the debates with Soviet historians and on Soviet historiography, as well as eulogies for Soviet historians, ${ }^{12}$ also form a part of this category, only outnumbered by works in French (over 50, including, however, only one aforementioned review of a book published in French). It is important to realize that the connection to Soviet academia was the only viable Eastern connection for a socialist historian before 1989 and that it was critical in the 1950s, which was also the formative period of Bardach's career. For example, in 1955 he was a representative of Polish historical sciences delegated to discuss the publication in Russian of a comprehensive history of Poland prepared by Soviet historians (Istorija Polszi), a debate in which Polish historical science took a critical stance concerning the Soviet view of Polish history, albeit phrased with the usual lip service to Soviet colleagues (see Rutkowski, 2008, p. 263ff). ${ }^{13}$ That Bardach was not unilaterally westward looking was an important asset for the new institutionalization of the history of law. ${ }^{14}$

\section{Conclusion}

Bardach's impact on the agenda of the history of law in socialism was complex and multidimensional, though not easy to measure in an exact manner. In the 1950s, he held a key position as a party scholar in determining the new organizational forms and research directions for Marxist historical science in Poland. In the 1960s, he lost much of his political influence, but he remained an established author, able to travel abroad much easier than many of his colleagues, well connected both in the East and in the West, keeping in touch with Soviet historical science while making a name for himself in Western international organizations and institutions. His work was largely a continuation of pre-war research agendas via direct personal links. He combined his commitment to the pre-socialist science of history, including its relative methodological openness and interdisciplinarity, with a focus on certain typically Marxist research topics, in particular on periodization. He was a very well-connected historian, an editor and an author of muchused reference books. In Bardach, the history of law gained a valuable asset in its constant interplay with historical science, but much less so in legal science, which contributed to its distancing from other branches of legal science.

Bardach's biographical trajectory shares certain transdisciplinary patterns observed in socialist academia. His status as a supervisor combined with the possibility that he was indeed a 'survivor in disguise'. It was not unusual in scholars born between 1910 and 1919 who seem to have been affected by a kind of a post-factum 'generational underdeterminacy'. Those born before 1910, like many of those with whom Bardach kept crossing paths constantly, including, for example, the influential sociologist and historian of ideas Nina Assorodobraj- 


\section{Marta Bucholc}

Kula (1908-1999), managed to finish their education well before the war and to take the first steps in their academic careers according to the European pre-war model, the memories of which they then carried on as survivors of bourgeois academic culture. Those born in the 1920s had no pre-war academic formation themselves; they were open to academic Marxism, predestined to play the role of supervisors of ideological takeover. They would include future revisionists like Leszek Kołakowski (1927-2009) or Zygmunt Bauman (1925-2017).

This generational mechanism was somehow reflected by the consequences of March 1968. Rutkowski wrote:

The effect of the March events was a takeover of the main role in historical science by historians of the younger generation, born at the turn of the 1920s and 1930s. Some of the scholars whose scientific activity culminated in the 1940s and 1950s, whose position was an established one, were pushed aside from the mainstream of state politics. They were tolerated because of their work and their position abroad, their functions at the universities and in foreign institutions, but they were treated with suspicion, so they were removed from influencing decisions in matters of science. This referred, among the others, to Juliusz Bardach (...). (Rutkowski, 2008, p. 589)

Younger historians who did not fall for the charms of revisionism and were loyal to the system made a speedy advance after 1968. Survivors-some of them-managed to survive, but their impact was meagre to the extreme apart from direct personal influence on their immediate students and colleagues. Bardach, who by his birthdate would qualify as a survivor, started his academic path with an almost five-year delay due to his army service, and it put him in an in-between position. He was established enough by 1968, but he was not considered trustworthy as a party scholar after that. This might have been a blessing for his work: he was no longer working on the ideological frontline. His scientific biography demonstrates the involvement of legal history in political, academic, cultural and intellectual agendas over the timespan of more than six decades. It also demonstrates the pivotal importance of an understanding of these agendas for a fuller grasp of what the history of law was and could be under socialism.

\section{Notes}

1 The biographical information in this section is based on the following: Filaszkiewicz (2016); Rutkowski (2008), p. 153; Olszewski (2010); Siewierski (2010) (2012); Szlachta (2014); and Zakrzewski (2016) as well as two scans of Bardach's admission documents from Stefan Batory University (a handwritten curriculum vitae and an enrolment form), kindly made available to me by Olga Filaszkiewicz, to whom I am very grateful.

2 His memories were published by the University of California Press in two volumes: Man Is Wolf to Man: Surviving the Gulag (1999) and Surviving Freedom: After the Gulag (2003) (both volumes together with Kathleen Gleeson).

3 My translation. 
4 A research institution established in 1944 to study the history of Polish-German relations, especially in the Recovered Territories.

5 Bardach received his $\mathrm{PhD}$ from Jagiellonian University; therefore, despite being a professor at the University of Warsaw, he was eligible for an honorary doctorate from the same.

6 Bardach's bibliography is available on the website of the Institute of History of Law of the Faculty of Law, University of Warsaw: http://bibliografia.ihp.wpia. uw.edu.pl/biblio2.php (retrieved December 17, 2019).

7 J. Bardach, Historia państwa i prawa Polski do potowy XV wieku, Warsaw 1957; Z. Kaczmarczyk, B. Leśnodorski, Historia państwa i prawa Polski od potowy XV wieku do 1795 roku, Warsaw 1957; Od rozbiorów do uwtaszczenia, J. Bardach, M. Senkowska - Gluck (eds.), Warsaw 1981; K. Grzybowski, Od uwtaszczenia do odrodzenia państwa, Warsaw 1982; Historia państwa i prawa Polski 1918-1939, F. Ryszka (ed.), cz. 1-2, Warsaw 1962, 1968.

8 In 1997, Bardach published a paper on the same subject, 'Wpływ prawa rzymskiego na Statuty litewskie oraz ich oddziaływanie na kraje sąsiednie' in the journal Lituania (1-2/1997, pp. 12-36).

9 'У Польщі іронічно зауважують: часто лише після смерті видатного поляка стає відомо про нього дві речі, що він був видатний і що він був єврей.'

10 In 1936 and 1937, Bardach reviewed of two volumes of a book by G. Wirschubski, Das Strafrecht des Litauischen Statuts, for the journal Ateneum Wilenskie (1936, vol. 11, pp. 516-518, and 1937, vol. 12, pp. 604-606).

11 He was a member of Société Jean Bodin and Société d'Histoire du Droit, as well as of Accademia Nazionale dei Lincei (since 1974) and Accademia Mediterranea delle Scienze (since 1982). He was also a Vice President of the Commission des Anciens Pays et Assemblées d'Etats et du Parlamentarisme and was President of the Commission for Slavonic Studies of the International Committee of Historical Sciences (1980-1985).

12 Including Boris Grekov, Lev Tcherepnin, Vladimir Pashuto, S. Youshkov.

13 A review, co-authored by Bardach, S. Arnold and S. Kieniewicz, of the first volume of this book was published in Polish in 1954 (Kwartalnik Historyczny 1954, No. 4, pp. 222-233) and in Russian (authored by Bardach alone) in 1955 ('Wiestnik Akademii Nauk SSSR' 1955).

14 Another trajectory of disciplinary development is shown by sociology, which did not have a comparable asset to legitimise a turn to the East-and avoided this turn almost entirely (see Bucholc, 2016).

\section{References}

Alexandrowicz, S. (2010) Wspomnienie o Profesorze Juliuszu Bardachu (3 XI 1914, Odessa-26 I 2010, Warszawa), Zapiski Historyczne, 4 (LXXV), 153-156.

Bajerski, A. (2016) Szkolnictwo wyższe międzywojennej Polski. Ujęcie geograficzne, Poznań: Wydawnictwo UAM.

Bal, M. (2002) Travelling Concepts in the Humanities: A Rough Guide, Toronto: University of Toronto Press.

Bardach, J. (1949) 'O periodyzacji dziejów w historiografii radzieckiej, Przegląd Historyczny 40, 22-52.

Bardach, J. (1951) 'Perspektywy rozwoju nauki historii państwa i prawa', Czasopismo Prawno-Historyczne 3, 1-10.

Bardach, J. (1990) Żydzi w Birżach radziwiłłowskich w XVII-XVIII wieku, Przeglad Historyczny, 81:1-2, 199-220. 


\section{Marta Bucholc}

Bardach, J. (1991) Rec. J. Kodrębski, Prawo rzymskie w Polsce XIX wieku (Łódź 1990), Przeglad Historyczny, 82:2, 335-337.

Bardach, J. (2001) Themis a Clio, czyli o potrzebie podejścia historycznego w prawoznawstwie, Warsaw: Liber.

Bardach, J. (2009) 'About Natives, Nativeness and Native Patriotism-Past and Present', in A Book of the Grand Duchy of Lithuania: Towards the Tradition of European Community. A Joint Publication of Scientists and Writers from Belarus, Lithuania and Poland, Sejny: Pogranicze.

Bardach, J. (2016) 'Ze wspomnień o Karolu Koranyim', in Baraniewski W., Tygielski W. and Wróblewski A. K., (eds) Portrety Uczonych. Profesorowie Uniwersytetu Warszawskiego po 1945 (A-K), Monumenta Universitatis Varsoviensis, Warsaw: Wydawnictwa UW, 521-525.

Bucholc, M. (2016) Sociology in Poland: To Be Continued?, London: Palgrave. DOI: 10.1057/978-1-137-58187-7.

Bucholc, M. (2017a) 'The Warsaw School of the Historians of Ideas as a Thought Collective: Together, Separately', The Interlocutor 1:1, 141-161.

Bucholc, M. (2017b) 'Nachruf für Jerzy Szacki. Historie', Jabrbuch des Zentrums für Historische Forschung Berlin der Polnischen Akademie der Wissenschaften, 11, 251-253.

Connelly, J. (2000) Captive University, Chapel Hill and London: University of North Carolina Press.

Czech-Jezierska, B. A. (2015) 'Powojenne losy nauczania prawa rzymskiego w Polsce Ludowej (1944-1989)', Krakowskie Studia z Historii Panstwa i Prawa, $8: 1,77-92$.

Dobra starość... (2007) 'Dobra starość to umiejętnosść wykorzystania doświadczenia', in A. Kobos, Po drogach uczonych. T. 2. Kraków: Polska Akademia Umiejętności, 491-524.

Filaszkiewicz, O. (2016) 'Juliusz Bardach-wileńskie lata', in Dąbrowski P. and Szpoper D. (eds) Stefan Ehrenkreutz $i$ historycy prawa okresu dwudziestolecia międzywojennego, Olsztyn: GWS, 87-98.

Garrison Walters, E. (1988) The Other Europe: Eastern Europe to 1945, Syracuse: Syracuse University Press.

Haferkamp, H.-P. (2018) Die historische Rechtsschule. Frankfurt am Main: Vittorio Klostermann.

Historia... (1955) Historia państwa I prawa polskiego, Cz. I, wedtug wyktadów prof. J. Bardacha przygotowali M. Pietrzak, W. Rostocki i St. Russocki, Warszawa: PWN.

Kühn, Z. (2011) The Judiciary in Central and Eastern Europe: Mechanical Jurisprudence in Transformation, Leiden and Boston: Brill and Martinus Nijhoff. DOI: $10.1163 / 9789047429005$.

Marszał, M. and Srokosz, J. (2010) 'Rzymianie czy barbarzyńcy? Z dyskusji nad reformą programu studiów prawniczych w Polsce w Latach 1931-1937’, in Acta Universitatis Wratislaviensis 3264, Przegląd Prawa i Administracji Lxxxiii, Wrocław: Wydawnictwo UWr, 263-286.

Materniak-Pawłowska, M. and Krzymkowski, M. (2018) "Siedemdziesiąt lat 'Czasopisma Prawno-Historycznego"”, Czasopismo Prawno-Historyczne, 70:1, 345-352.

Mączak, A. (1993) 'National Traditions in the Historiography of the State: the Case of Poland', Actes du colloque de Rome (18-31 mars 1990), Publications de l'École Française de Rome, Année 1993, 171, 235-248. 
Olszewski, H. (2010) 'Wspomnienie o Juliuszu Bardachu (1914-2010)', Nauka 1, 159-163.

Olszewski, H. (2015) Ludzie Uniwersytetu w mojej pamięci, Poznań: Wydawnictwo UAM.

Olszewski, H. (2017) Kilka uwag o prawniczych studiach II stopnia w latach 1952-1954, Acta Universitatis Wratislaviensis 3780 Studia nad Autorytaryzmem i Totalitaryzmem, 39:2, 89-113.

Popper, K. R. (1994) The Open Society and Its Enemies, New Jersey: Princeton University Press.

Rosner, A. and Wąsowicz, M. (eds) (2004) Z dziejów kultury prawnej: studia ofiarowane Profesorowi Juliuszowi Bardachowi w dziewięćdziesięciolecie urodzin, Warsaw: Liber.

Rutkowski, T. (2008) Nauki historyczne w Polsce 1944-1970. Zagadnienia polityczne $i$ organizacyjne, Warsaw: Wydawnictwa UW.

Rutkowski, T. (2016) 'Na styku nauki i polityki. Uniwersytet warszawski w PRL 1944-1989', in Baraniewski W., Tygielski W. and Wróblewski A. K. (eds) Dzieje Uniwersytetu Warszawskiego po 1945, Monumenta Universitatis Varsoviensis, Warsaw: Wydawnictwa UW, 375-692. DOI: 10.31338/uw.9788323522041.pp.375-692.

Siewierski, T. (2010) 'Juliusz Bardach (1914-2010): o lituanistycznej pasji uczonego' (http://mlodszaeuropa.pl/index.php?option=com_content\&view=article\&id=71: juliusz-bardach-1914-2010-o-lituanistycznej-pasji-uczonego\&catid=18:dziedzictwoartykuy\&Itemid=6; retrieved 17.12.2019).

Siewierski, T. (2012) 'Juliusz Bardach (1914-2010): o lituanistycznej pasji uczonego', in Czyżewska U., Siewierski T., Tabaszewski R. and Żołnierz J. (eds) Multum, non multa. Mtodzi badacze w poszukiwaniu prawdy, Lublin: Wydawnictwo KUL, 107-120.

Sokalska, O. (2017) 'Юліуш Бардах-Історик Права На Перехресті Епох I Держав (До Витоків Родоводу Вченого)', Вісник Пенітенціарної Асоціації України, 2, 13-19.

Sułek, A. (2012), 'Jerzy Szacki, encyklopedysta', Przeglad Filozoficzno-Literacki, $35: 4,43-45$.

Szlachta, B. (2014) 'Juliusz Bardach (1914-2010)', in Kozub-Ciembroniewicz W. (ed) Uczeni żydowskiego pochodzenia we wspótczesnych dziejach Uniwersytetu Jagiellońskiego, Kraków: Wydawnictwo UJ, 77-85.

Thornhill, C. (2011) A Sociology of Constitutions, Cambridge: Cambridge University Press. DOI: $10.1017 / \mathrm{CBO} 9780511895067$.

Wandycz, P. S. (1992) 'Historiography of the Countries of Central and Eastern Europe: Poland', The American Historical Review, 97:4, 1011-1025.

Wołodkiewicz, W. (2015) 'Nauczanie prawa czy przepisów prawnych', Czasopismo Historyczno-Prawne, 67:1, 233-247. DOI: 10.14746/cph.2015.68.1.12.

Wołodkiewicz, W. (2012) 'Czy prawo rzymskie będzie istnieć?', Palestra 9-10, 203-212.

Zakrzewski, A. (2016) 'Juliusz Bardach. 1914-2010', in Baraniewski W., Tygielski W. and Wróblewski A. K. (eds) Portrety Uczonych. Profesorowie Uniwersytetu Warszawskiego po 1945 (A-K). Monumenta Universitatis Varsoviensis, Warsaw: Wydawnictwa UW, 57-62. DOI: 10.31338/uw.9788323523314.pp.56-63.

Z prac... (1950) 'Z prac Podsekcji Prawa I Kongresu Nauki Polskiej', Państwo $i$ Prawo 11:5, 97-114.

Zysiak, A. (2018) 'Postwar Modernization and the University for the Working Classes in Poland', in Karady V. and Hincu A. (eds) Social Sciences in the Other Europe Since 1945, Budapest: Pasts, Inc., Central European University, 29-51. 